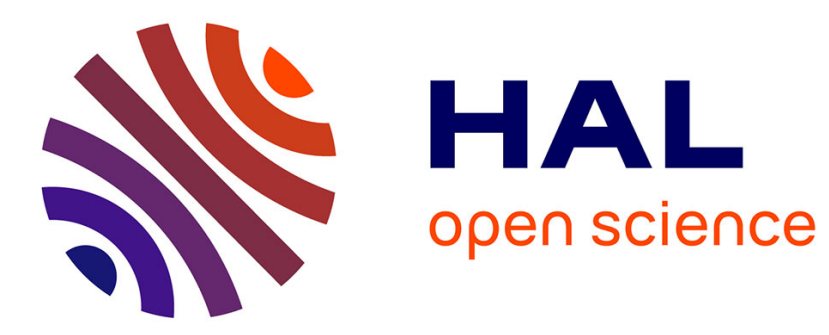

\title{
Internationalization strategies of business schools - how flat is the world?
}

\author{
Bertrand Guillotin, Vincent Mangematin
}

\section{To cite this version:}

Bertrand Guillotin, Vincent Mangematin. Internationalization strategies of business schools how flat is the world? . Thunderbird International Business Review, 2015, 57 (5), pp.343-357. 10.1002/tie.21705 . hal-01265950

\section{HAL Id: hal-01265950 \\ http://hal.grenoble-em.com/hal-01265950}

Submitted on 1 Feb 2016

HAL is a multi-disciplinary open access archive for the deposit and dissemination of scientific research documents, whether they are published or not. The documents may come from teaching and research institutions in France or abroad, or from public or private research centers.
L'archive ouverte pluridisciplinaire HAL, est destinée au dépôt et à la diffusion de documents scientifiques de niveau recherche, publiés ou non, émanant des établissements d'enseignement et de recherche français ou étrangers, des laboratoires publics ou privés. 


\title{
INTERNATIONALIZATION STRATEGIES OF BUSINESS SCHOOLS - HOW FLAT IS THE WORLD? ${ }^{1}$
}

\author{
Bertrand Guillotin \\ bertrand@duke.edu \\ Grenoble Ecole de Management \\ Vincent Mangematin \\ vincent.mangematin@grenoble-em.com \\ Grenoble Ecole de Management
}

\section{EXECUTIVE SUMMARY}

Business school strategy has become more complex than ever, especially regarding internationalization. Using different paths, experiencing failure and success, business schools have internationalized, attracting many of the international students who contributed $\$ 27$ billion $^{2}$ to the US economy in 2014. Some business schools are global, training global managers, others are more focused on national markets. How do business schools strategize about internationalization? Can we use existing models to explain this process? Are internationalization and globalization similar? Using a comparative analysis of six case studies in the US and Europe, we found that the engine of internationalization influences its paths and outcomes. We contribute to the body of IB research by discussing how business schools strategize their internationalization toward uniformity or diversity under isomorphic pressures from accreditation bodies (AACSB, 2011) and rankings. The so-called Uppsala model should be

\footnotetext{
${ }^{1}$ Acknowledgements: the authors would like to thank two anonymous and rigorous TIBR reviewers for their detailed and useful feedback, as well as Prof. Richard M. Burton, professor emeritus of organization and strategy (Duke University), for his pertinent comments and continuous support. Also, we acknowledge that some of the findings in this paper were presented at peer-reviewed colloquia (EGOS 2013 and EGOS 2014).

2 Institute for International Education, Open Doors Data, http://www.iie.org/Research-and-Publications/OpenDoors/Data/Economic-Impact-of-International-Students
} 
extended to deal with three tensions: internationalization vs. globalization, enacted dimensions of audiences, and respective risks of different internationalization pathways.

Key words: business schools, disruptions, internationalization, globalization, strategies, knowledge.

\section{INTRODUCTION}

Disruptions in the field of business education are not new. Since the Gordon report (Gordon \& Howell, 1959), business education has been the legitimate producer of scientific knowledge about management. The 1980's globalization of markets (Levitt, 1983) including that of education ones (Khurana, 2007) brought a new challenge for business schools. Business schools went beyond domestic markets, using a process similar to the internationalization of the firm (Johanson \& Vahlne, 1977, 2009a). They defined strategies based on the so-called Uppsala model to internationalize (De Meyer, Harker, \& Hawawini, 2004; Engwall \& Kipping, 2013). Using different internationalization mechanisms and strategies many national players were propelled onto the international scene. They internationalized, attracting many of the international students that contributed $\$ 27$ billion $^{3}$ to the US economy and millions to their own revenues during the 2013-2014 academic year.

Since markets became more distant and more complex, management education required quality signals. Certification through independent agencies built international legitimacy (Durand \& McGuire, 2005). AACSB, EQUIS and AMBA established internationalization quality standards (Engwall, 2007). In the 2000's, rankings became highly visible, both at the national and international levels. Pushed by calls for action (Doh, 2010), pressures from the media via global rankings (Wedlin, 2006, 2007, 2011), and employers' demand for global talent, many business

\footnotetext{
3 Institute for International Education, Open Doors Data, http://www.iie.org/Research-and-Publications/OpenDoors/Data/Economic-Impact-of-International-Students
} 
schools ventured further onto their internationalization journey. They imitated leaders, such as INSEAD which had launched its first international campus in Singapore (2000) before opening a second one in Abu Dhabi (2007). As they were venturing on this journey, Pulitzer-prize winner, Thomas Friedman reassured the deans with his best-seller, "The World is Flat" (Friedman, 2005). However, world-renowned IB scholars and strategists, explained that our world is rather bumpy and semi-globalized (Ghemawat, 2007a, b, 2008, 2011) and that only a few companies are actually global (Rugman \& Verbeke, 2004). Regardless, many schools joined the global arms race to build international branch campuses (IBCs), considered the mandatory "advanced phase in the evolving process of internationalization" (Bartell, 2003). Along with universities, business schools did so by the hundreds (C-BERT, 2014; Wilkins \& Huisman, 2011, 2012), sometimes paying dearly for failures (Alajoutsijärvi, Juusola, \& Lamberg, 2014), pursuing international and/or global strategies to address management education markets. In the middle of that race, respected international management education scholars also reminded everyone that labor markets remain fiercely domestic and that the internationalization of management education has its own limitations (Engwall \& Kipping, 2013).

Internationalization is seen as imperative. However, it remains ambiguous as the demand for global managers remains limited, domestic markets dominate and need managers with international capabilities. Implicitly, everyone refers to the Uppsala model to define strategies while audiences, goals, reputation and legitimacy differ. Using similar analysis on professional service firms (Caravan, Sharkey Scott, \& Mangematin, 2012), we seek to better understand the engine of internationalization. Our research design and methods are based on the comparative case studies of six business schools in the US and Europe. We collected archived information and we interviewed the top management of these business schools. To analyze data, we used 
NVivo 10 to code our data and identify themes and patterns (Miles \& Huberman, 1994). Based on qualitative approach on engines of internationalization (Doz, 2011), we contribute to the body of IB research by identifying the engine of internationalization which influences: 1) the nature of internationalization (globalization or internationalization); 2) the possibility for each school to enact its markets and 3) the risk profile based on a school's engagement.

\section{LITERATURE REVIEW}

Defined as knowledge-intensive service firms (Czinkota, Grossman, Javalgi, \& Nugent, 2009; Javalgi \& Grossman, 2014), business schools ${ }^{4}$ are more specifically professional service firms (PSFs) according to Von Nordenflycht (2010). They are implicitly following the step-by-step Uppsala model to internationalize while the paths of internationalization seems more diverse.

\section{Internationalization of education and globalization}

Using the AACSB report on the globalization of management education (2011), we would like to emphasize the differences between globalization and internationalization. According to conventional definitions, globalization is what "pushes an enterprise, its products, and its services across national borders; it promotes interaction and engagement on a global scale; it advances networking, communications, and execution of transactions; it spreads trade, investment and technology; and it integrates nations politically, economically, and culturally" (AACSB, 2011). On the other hand, the "internationalization of education consists of policybased responses that education institutions adopt as a result of the impact of globalization"

\footnotetext{
4 AACSB's expertise on the definition of business schools (http://www.aacsb.edu/about/our-reach/): 1) Business schools must be legally operating tertiary-level educational institutions. 2) They must confer at least one Bachelor's degree or higher. 3) The award(s) in question must be conferred in their own name, i.e., bearing the name of their own institution, and not simply be validated or franchised through another institution.
} 
(Naidoo, 2006). Our analysis focuses on responses (Knight, 1999) that materialize in "funded programs that facilitate institutions and individuals to have opportunities to engage in international activities such as mobility, research, and linkages (Knight, 2004).

As a consequence of these definitions, internationalization is associated with multiculturalism, diversity and divergence, while globalization is associated with standardization, centralization, and convergence (Antunes \& Thomas, 2007). Additionally, internationalization goes beyond student and faculty mobility (Luijten-Lub, Van der Wende, \& Huisman, 2005); it should affect the whole business school (Bruner \& Iannarelli, 2011; Hudzik, 2011). In terms of knowledge production, international knowledge is "affected by local markets, culture, regulations, and other idiosyncratic factors where specific regional and local insights are essential" whereas global knowledge and insights deal with "universal truths (business operations, human behavior, and financial analysis)" where "a more centralized and disciplinary focus is appropriate" (De Meyer et al., 2004).

Business schools are professional services organizations which have demonstrated a large variety of internationalization processes while the environment is highly institutionalized and should lead to highly converging strategies. To what extent do existing models reflect these processes?

\section{Models of internationalization}

The Uppsala model is one of the key references when studying internationalization processes of the firm (Johanson \& Vahlne, 1977; Johanson \& Vahlne, 2009b).

The Uppsala model: internationalization of the firm

According to this seminal paper, internationalization for small, medium enterprises is a step-bystep process that is highly constrained and standardized. During the first step, the firm exports sporadically. Gaining knowledge and confidence, it then starts exporting more regularly, using 
the services of a representative (step two). During the third step, the firm establishes a foreign subsidiary to sell in a given market. To complete the process, the production function is added to that of sales (step four). The last two steps are considered Foreign Direct Investment (FDI). Responding to criticisms (Forsgren, 2002) and context changes, this 1977 model was amended in 2009. The 2009 model describes the business environment as a "web of relationships" (Johanson \& Vahlne, 2009a) and "borderless" (Johanson \& Vahlne, 2009a). While acknowledging a more global world, the authors reiterate a stepwise process, considering the "born global" firms as "born regionals" in reality with "international activities that do not really span the globe" in any significant way (Johanson \& Vahlne, 2009a; Rugman \& Verbeke, 2007).

\section{Translation of the Uppsala model for Higher Education internationalization}

Adapting the Uppsala model, Engwall and Kipping identify four mechanisms based on two analytical dimensions (Engwall \& Kipping, 2013): the location of the delivery and the origin of the students. They include the following:

- Import of ideas: internationalization without mobility of persons, delivered in the home country, knowledge imported through international research networks, business schools models and templates, textbooks from leading US professors, gurus, and consultants.

- Outsourcing: internationalization through mobility, delivered in the host country, teaching of students and their exposure to an international context is outsourced to exchange partners.

- Insourcing: internationalization through international student and/or faculty, delivered in the home country. 
- FDI: internationalization through investment abroad requiring the highest level of commitment, and representing the highest financial and reputational risks, delivered in the host country.

Engwall and Kipping describe a step-by-step process where organizations combine different mechanisms to internationalize. Strategic decisions include, not only the use of one of the models, but also the combination of different mechanisms to conduct the internationalization process. De Meyer, Harker, and Hawawini adapt the mechanisms to business schools. They specify (De Meyer et al, 2004, p. 108) two mechanisms in addition to importation/exportation of students, faculty, and ideas:

- Partnering (reciprocal student exchanges and other partnerships are formed).

- Network building (new campus(es) built in addition to a main campus).

On the one hand, the De Meyer et al's export model (i.e., the Enwall and Kipping's import of ideas model seen from the perspective of the knowledge producer), and the network model (branch campus strategy) are the models that best describes a global strategy based on scope. On the other hand, the other mechanisms describe an international strategy based on people's mobility which by design has a more limited scope and is more inter-national or between countries. De Meyer et al also explain that combining two models or mechanisms leads to hybrid models (partnering and network models: INSEAD and Wharton); the models can also evolve over time based on cost and benefits: Following its very successful Global Executive MBA venture in 1996, Duke University's Fuqua School of Business ventured into Germany. However, its satellite campus strategy failed (campus closed in 2002) and led to a less resource-intensive partnership with Seoul National University in 2003 (De Meyer et al., 2004). Epilogue: these experiments gave the Fuqua School of Business the knowledge and confidence to go into 
unchartered territories, such as Kazakhstan with yet a different model and to launch the Master of Management Studies at Duke-Kunshan University in China in 2014. The Chicago Booth School of Business also experimented with IBCs by opening some in Barcelona and Singapore and later moving them to London and Hong-Kong (2013). 
The following table described the three step-by-step internationalization models and mechanisms:
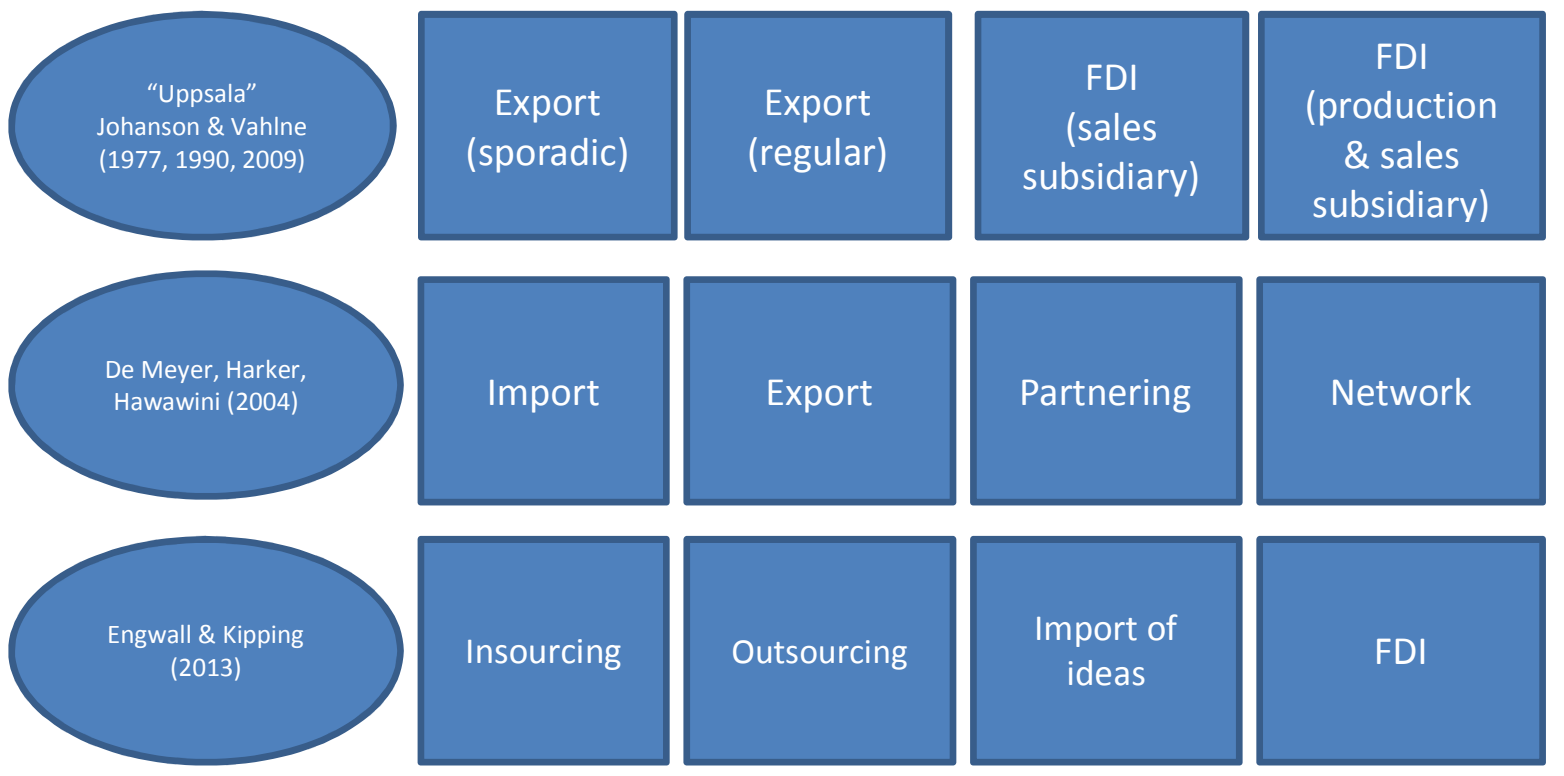

Among the mechanisms mentioned above, the network model or IBC strategy has been on the rise. In 2014, there were 201 IBCs worldwide (C-BERT, 2014), up from 183 three years earlier, mostly in the UAE, China, Singapore, and Qatar (Wilkins \& Huisman, 2012).

While the step-by-step model considers markets as homogeneous, professional service firm literature integrates different audiences as key drivers for internationalization. It seems important, not only to consider the steps of development, but also to understand the engines of internationalization. Based on the engines, strategies may be richer and more relevant to internationalize the activities of business schools. The paper is designed to identify engines of internationalization to differentiate between internationalization and globalization strategies and to refine strategic actions for business schools. 


\section{DATA AND METHOD}

\section{Research design}

To better understand how business schools internationalize, we use a comparative case study analysis of 6 business schools in 3 countries (US, France, and Austria). Comparative case studies are the appropriate method to explore the variety of internationalization and its effects on globalization or internationalization (Birkinshaw, Brannen, \& Tung, 2011; Eisenhardt, 1989).

We designed our research around six US and European case studies as primary research sources. Through semi-structured interviews, we collected 569 pages of data (interview transcripts and field notes) that helped us reach some data saturation. The same interviewer for all interviews used an interview protocol (Eisenhardt, 1989), improved after a test interview, and discussed themes rather than asked questions from a rigid questionnaire to keep each interview like a conversation (Yin, 2009). We used a naturalistic approach (Wilson \& Sapsford, 2006). To validate our preliminary observations and findings and to gain additional insights, we conducted interviews with experts from the foremost accreditation bodies in the world: the AACSB and EQUIS (Thomas, Billsberry, Ambrosini, \& Barton, 2013). We shared our findings with some informants. As secondary research sources, we used academic journals and doctoral theses, websites, conference proceedings, strategic plans, annual reports, professional association task force reports, and specialized newspaper and magazine articles. Our unit of analysis is the business school strategy. We focus on business schools that deliver an MBA (Master of Business Administration). 


\section{Data collection}

Six cases were selected in Europe and the US where most accredited business schools reside. Data were gathered between 2012 and 2014 in three countries through 39 semi-structured interviews representing a total of 34.8 hours. The interviews were conducted as guided conversations (Yin, 2009) with key informants: deans, heads of departments (faculty or administrators) whose efforts had been closely linked to internationalization and strategic decision-making and to whom we had direct access. Direct access is important in this industry sector because experts are typically reluctant to share their perspectives on complex issues, such as internationalization, within their own professional internal environment (Scherer, Javalgi, Bryant, \& Tukel, 2005). Triangulation of our findings and additional insights were obtained from experts of accrediting agencies: EQUIS and AACSB International.

Half of the interviews were conducted face-to-face and on site, typically in the informant's office and half of them on the phone. Interviews were recorded and transcribed by professionals. Follow-up emails and additional phone conversations helped clarify some of the data with informants to increase external validity (Flick, 2007). They were supplemented by field and interview notes, mostly taken on the spot and expanded upon, as soon as possible after interviews, when recording was not an option. We used multiple sources of evidence (Yin, 2009) to validate our constructs (Peräkylä, 1997) and to triangulate our data by comparing them with website data, articles, as well as internal strategic documents, annual reports when available, and or our own observations. Triangulation, often used in social sciences, actually comes from navigation "where multiple approaches are undertaken to establish a point" (Burton \& Obel, 2011). "Triangulation is used to gain a deeper and better understanding and can include what might-be methods, as well as complementary approaches such as field studies, case studies and 
keen observation in order to offset the limitations of a single approach" (ibid). No funding was provided for this study. Access to data and informants was obtained in the capacity of current or former student, peer, or professional association leader (Partnership in International Management) and a snowballing approach using direct referrals from known informants to build trust between interviewer and interviewee (Noy, 2008) and gain greater access to new informants. To present the cases, we map them out according to the following six criteria:

1. Date of creation, which is important to appreciate renown;

2. Prestige or reputation. Prestige is considered as a durable asset here and is mainly generated by research in top academic journals; i.e., universal (global) knowledge that is based on disciplines and not market-specific knowledge. Reputation is audience-specific and more labile.

3. Level of funding and sources of financing. Based on the 2012-2013 budget and its composition amongst different sources of funding, it is categorized as low, medium or high;

4. Accreditations, which informs the quality of the process;

5. Ranking, which informs the relative positioning amongst the national business schools;

6. Knowledge production. Is knowledge production specialized or general? 
Table 1: Description of the cases

\begin{tabular}{|c|c|c|c|c|c|c|c|}
\hline Case & Established & $\begin{array}{c}\text { Prestigious* (P) } \\
\text { Reputable (R) }\end{array}$ & $\begin{array}{c}\text { Level of } \\
\text { Financial } \\
\text { Resources }\end{array}$ & $\begin{array}{c}\text { Number of } \\
\text { Financing } \\
\text { Sources }\end{array}$ & Accreditations & $\begin{array}{c}\text { National } \\
\text { Ranking } \\
\text { Status }\end{array}$ & $\begin{array}{c}\text { Knowledge } \\
\text { Produced }\end{array}$ \\
\hline FR1 & 1900 's & $\mathrm{R}$ & Low & $\begin{array}{c}\text { Low- } \\
\text { Medium }\end{array}$ & EQUIS** & First tier & $\begin{array}{c}\text { Market- } \\
\text { specific }\end{array}$ \\
\hline FR2 & 1880 's & $\mathrm{P}$ & High & High & $\begin{array}{c}\text { EQUIS, } \\
\text { AACSB, } \\
\text { AMBA }\end{array}$ & Top 10 & Universal \\
\hline FR3 & 1980 's & $\mathrm{R}$ & Medium & Medium & $\begin{array}{c}\text { EQUIS, } \\
\text { AACSB, } \\
\text { AMBA }\end{array}$ & Top 10 & $\begin{array}{c}\text { Market- } \\
\text { specific and } \\
\text { universal }\end{array}$ \\
\hline A1 & 1890 's & $\mathrm{R}$ & High & Low & $\begin{array}{c}\text { EQUIS and } \\
\text { AMBA }\end{array}$ & $\begin{array}{c}\text { Top 10 } \\
\text { Market- } \\
\text { specific }\end{array}$ \\
\hline US1 & 1940 's & $\mathrm{R}$ & Low & Low & $\begin{array}{c}\text { AACSB } \\
\text { (EQUIS } \\
\text { accredited in the } \\
1990 \text { 's) }\end{array}$ & $\begin{array}{c}\text { Second } \\
\text { tier }\end{array}$ & $\begin{array}{c}\text { Market- } \\
\text { specific }\end{array}$ \\
\hline US2 & 1960 's & $\mathrm{P}$ & High & High & AACSB & Top 10 & Universal \\
\hline
\end{tabular}

*Prestige is considered as a durable asset here and is mainly generated by research in top academic journals; i.e., universal (global) knowledge that is based on disciplines and not market-specific knowledge.

**3-year provisional accreditation since 2007, as opposed to 5 years for schools deemed of higher quality.

\section{Data analysis}

The data were analyzed based on the recommended approach of within-case and across-case analysis (Eisenhardt, 1989; Eisenhardt \& Graebner, 2007) searching for themes and patterns (Miles \& Huberman, 1994). To support the analysis, to give it a backbone (Charmaz, 2006), a Computer Assisted Qualitative Data Analysis Software (NVivo 10) was used to code in cycles based on the recommendations of experts that have mastered this technique (Bazeley \& Jackson, 2013; Saldaña, 2013). Accordingly, our coding yielded fifteen themes and were then regrouped into five aggregated mechanisms. Our coding approach was both inductive and deductive and it included matrix coding queries that are aimed at displaying patterns across data and across nodes. It is useful to "see responses in different contexts, or to different issues, or to consider the impact of various strategies (NVivo 10 Manual p. 27) . $^{5}$ Furthermore, it is explained that

\footnotetext{
${ }^{5}$ http://www.researchsupport.com.au/NV_10_notes.pdf
} 
"pattern coding identifies similarly coded data and organizes the corpus of data into sets, themes, or constructs and attributes meaning to that organization." It is an appropriate method for second cycle (order) coding (Saldaña, 2013). Additionally, it helps "develop major themes from the data; search for rules, causes, and explanations in the data; examining social networks and pattern of human relationships; or the formation of theoretical constructs and processes" (ibid). Additionally, writing and re-writing findings in analytic memos (Denzin \& Lincoln, 2000), as well as making graphical representation of relationships between themes helped us refine our analysis. This interactive process between rich data and evolving theory provided the theoretical insights that we share below in order to contribute to the body of IB research which lacks contributions with a qualitative approach (Doz, 2011).

Our data were analyzed and interpreted while limiting the impact of potential biases that come naturally and by comparing them with the evidence in the literature (Yin, 2009). While generalization is very limited due to the nature of our empirical approach, we believe that these cases reflect some patterns (Miles \& Huberman, 1994), what we know, and what we have observed over the years as practitioners. Our observations were made in the capacity of faculty, staff, and sometimes as former or current student of the business schools studied. More specifically, the cases were compared and the data were analyzed and interpreted based on the following criteria to investigate the strategic diversity of the actors (table 2):

- Main rationale for internationalization (why)

- Main internationalization mechanisms used (how), leveraging De Meyer et al (2004)

- Scope of strategy (international vs. global). 
Table 2: Internationalization vs. Globalization

\begin{tabular}{|c|c|c|c|c|}
\hline \multirow{2}{*}{ Case } & \multicolumn{2}{|c|}{ Internationalization } & \multicolumn{2}{c|}{ Scope/Focus of Strategy } \\
\cline { 2 - 5 } & Rationale (why) & Mechanisms* (how) & International & Global \\
\hline FR1 & $\begin{array}{c}\text { - Accreditations requirements } \\
\text { - Income }\end{array}$ & Partnering and limited network building & \\
\hline FR2 & $\begin{array}{c}\text { - Recruiters' needs } \\
\text { - Competition }\end{array}$ & Import, export, and partnering & $\mathrm{X}$ \\
\hline FR3 & $\begin{array}{c}\text { - Rankings } \\
\text { - Recruiters' needs }\end{array}$ & Import, limited export, and partnering & $\mathrm{X}$ & \\
\hline A1 & $\begin{array}{c}\text { - Initial strategic positioning } \\
\text { - Recruiters'needs }\end{array}$ & Import and partnering & \\
\hline US1 & $\begin{array}{c}\text { - Initial strategic positioning } \\
\text { - Recruiters'needs }\end{array}$ & $\begin{array}{c}\text { Import, export, and network building } \\
\text { - }\end{array}$ & & \\
\hline US2 & $\begin{array}{c}\text { - Recruiters' needs } \\
\text { - Competition }\end{array}$ & $\begin{array}{c}\text { Import, export, some partnering, and } \\
\text { network building }\end{array}$ & & $\mathrm{X}$ \\
\hline
\end{tabular}

*Using the De Meyer et al (2004) model of business education internationalization.

\section{RESULTS AND DISCUSSION}

The analysis of data reveals four different results: first, the definition of internationalization is not similar on both sides of the Atlantic. Second, business schools are not only determined by isomorphic pressures. They also enact their markets and their environment. Third, as a consequence of internationalization perception and audience selection, the focus of business school internationalization strategies is either global or international. Finally, their risk adversity influences their internationalization strategy and their international or global commitments.

\section{International or global}

The definition of internationalization is not global but rather locally embedded. For European business schools, internationalization of higher education is associated with multiculturalism, as well as student and faculty mobility. Quotes of business schools deans illustrate the European view.

"I think that in Europe we have a very different vision of internationalization than in the US."

Associate Dean and Director of Quality, FR3 business school (3/27/2014)

"We view internationalization more as a European activity, more or less." 
Vice Rector, International Affairs and Research, A1 business school (8/21/2013)

"In our conversations, we never talk about the globalization of Al business school, we talk about the internationalization of Al business school.”

Dean, International Affairs, A1 business school (8/2/2013)

"Internationalization is based on diversity, cross-cultural enrichment and no single best approach, whereas, "globalization is associated with convergence to a single mode and one best way."

Associate Dean and Director of the Grande Ecole, FR2 business school $(5 / 30 / 2013)$

Most of European business schools will use the import and partnering mechanisms of De Meyer et al that amount to an international strategy, limiting financial and reputational commitments.

In the U.S., internationalization equates to globalization and some scholars use the terms almost interchangeably (AACSB, 2011).

"I've more or less used them interchangeably in my conversation with you. What I think is important though, often when I use the term internationalization, I'm really focusing on understanding differences between countries. When I talk about globalization I'm usually talking about instances where those differences matter less."

AACSB Senior Executive (5/7/2014)

"We can argue all night about what each one means. Internationalization is related to importexport, inter-nations. Globalization refers to a process about reaching the world and is the preferred term. We are talking about the same thing. However, internationalization is somewhat passé, the same way MNCs are now called Global Companies.”

Marketing Faculty and Vice-President, US1 business school (5/23/2013) 
"Globalization is more of a phenomenon that we have to respond to."

Director, Doctoral School, FR3 business school (3/14/2014)

Global processes will tend to be uniformly replicated; i.e., faculty teaching the same, standardized, program around the world using mainly Harvard Business School cases and business schools overall adopting the same model of research-based excellence (Brewer, Gates, \& Goldman, 2002). Business schools on each side of the Atlantic seem to structure themselves and operate differently. Indeed, US business schools use De Meyer et al's export and network building mechanisms that amount to a global strategy carrying the greatest financial and reputational commitments (FDI). Such a difference is also revealed within AACSB and EQUIS reports, standards, and characteristics of these regulators.

"Within the standards of the accreditations, I would say that EQUIS, the European accreditation is the one that has always been the most forthright in terms of requirements for internationalization for a school.” “.. AACSB chose to use the term globalization in their standards.”

Associate Dean and Director of Quality, FR3 business school (3/26/2014)

"So, diversity, corporate connections, intellectual contributions, and internationalization would be the four distinguishing characteristics of EQUIS. And AACSB, although it obviously changes its standards over time, is very academically oriented, very program-focused and pays much less attention to internationalization than EQUIS does."

EQUIS Senior Executive (5/1/2014)

"EQUIS is tougher on internationalization than AACSB is."

Associate Dean and Director of International Relations, FR3 business school $(3 / 27 / 2014)$ 
Neither the process, nor what we call internationalization, seems to benefit from a globallyaccepted definition. US schools have been strategizing internationalization, implementing a strategy to train global managers on US standards, whereas the mobility of students and faculty within different European countries contributes to the EU construction.

\section{Enacting markets, choosing audiences}

When they are choosing whom to address, business schools enact their markets and their environment while choosing their audience. Isomorphism is locally embedded. Without oversimplifying differences, we consider two main types of business schools: the prestigious and prestige-seeking ones vs. the others that are less well-known and are categorized as reputable and reputation-seekers (Brewer et al., 2002). Clearly, this dichotomy provides business schools with different assets when internationalizing.

We find that the prestigious and established business schools; i.e., the elite, keeps tight circles (Stookey, 2008) and relies on its prestige and fame to select the best students, hire faculties from other elite schools, and attract the largest amount of funding (Brewer et al., 2002). Within its exclusive club, elite business schools enjoy stable rankings, due to the anchoring effect theory (Bowman \& Bastedo, 2011) and train the limited number of global managers who are needed by the few companies that are truly global (Rugman, 2012). However, labor markets remain domestic and the number of truly global business schools is very small (Engwall, 2013; Engwall \& Kipping, 2013). Global business schools benefit from a strong brand equity. As renown and fame take time to build and share, the geographic repartition of global business schools is unequal. While there are a few prestigious and global business schools in Europe, most of them are based in the US and they dominate the field (Engwall, 2007). 
The reputation-seekers; i.e., most business schools, are by definition not as famous or as visible as Harvard or Wharton. They rely on accreditations and rankings to build their reputation, increase their visibility; they serve a wider base (audience) of international customers. As an example, the race to earn the triple-crown accreditation (AACSB, EQUIS, Association of MBA), led by European reputation-seekers for them to get greater visibility and distance themselves from their competition, reveals the importance of quality signals to gain visibility and legitimacy. No US prestigious business school is on that list $^{6}$; fame does not need quality signals to attest its value to the chosen audience. Using rankings as reputation-builders, most business schools monitor them closely. Unlike the anchored position of the elite, the position of reputation-seekers in rankings is contestable. Rankings are also crucial financially, since enrollments (and revenues) go down when rankings do. "Nearly every admissions director interviewed reported that students' decisions correlate with rankings: if a school's rank declines, they lose students to schools to which they had not lost them in the past and vice versa" (Espeland \& Sauder, 2007). When imitating the elite in their global strategies to build IBCs, some business schools take great reputational and financial risks. Attracted by this growth but high-risk strategy, several schools, such as Michigan State University (MSU), were forced to leave the opulent city of Dubai once the bubble burst. Reasons cited include profitability issues and inability to recruit and keep enough students matriculated (Alajoutsijärvi, Juusola, \& Lamberg, 2014, p. 19). A lack of global brand equity to satisfy their global ambitions was probably another factor. In Europe, most business schools cannot match the U.S. resources and the diversity of their origin. They invest in their reputation, not prestige, and must conform closely to accreditation standards (e.g., internationalization).

\footnotetext{
${ }^{6}$ List of triple-crown accredited schools: $\underline{\text { http://en.wikipedia.org/wiki/Triple accreditation }}$
} 
We also find that internationalization is a way to increase social capital (reputation and networks) and income, especially for business schools that are not leaders in research. By creating this social capital, reputation-seekers internationalize through strategic and exclusive partnerships, such as the Partnership in International Management (PIM) network. Such a partnership enables members to erect a barrier of entry against any other competitor. Since 1973, this network has only accepted an average of 1.5 schools per year as new members and was started by prestigious European schools such as HEC Paris and London Business School (Engwall \& Kipping, 2013). As PIM members, reputation-seekers benefit from the prestige of the top schools, exchanging students with them without having to pay any fees. This is a great opportunity for reputation-seekers to differentiate themselves, build their brand equity, and recruit students internationally.

"We saw this as an opportunity to link up with some of the fine schools in [Western] Europe. Although, you have to keep in mind that this was 25 years ago."

Vice-Rector, International Affairs and Research, A1 business school with almost 300 exchange partners worldwide today, on joining the PIM network (8/21/2013) However, while borrowing prestige may be harmless, imitating top research producing business schools by joining their club (e.g., AACSB) can be a dangerous strategy for a school whose main asset is its reputation, not its prestige.

"The AACSB was our club of reference."

"Our school also faced the dilemma of the big fish in a small pond (IB) [field] or the small fish in a big pond (MBAs). We got confounded in the big pond (MBAs). The world came to us. All schools started to teach IB and at a lower cost."

Marketing Faculty and Vice-President, US1 business school (5/23/2013) 
Additionally, relying on accreditation can be misleading. Accreditation bodies (even at the regional level in the U.S.) can withdraw support and put a reputable business school in trouble (Korn, 2014).

"In the absence of support from their regulator, we respect that they need to pursue a different structure with a different partner."

Laureate Education, Inc. spokesman, Matthew Yale, on the proposed jointventure between Thunderbird and Laureate (ibid).

"The multi-million dollar joint-venture would have shored up the finances of the cash-strapped business school" (Korn, 2014).

In addition to using accreditations and rankings, most European schools use differentiation strategies, leveraging niche markets with an international audience. Examples include Ashridge and Henley which focus on practice, not research, and the Imperial (Tanaka) school which has "adopted a technology and knowledge focus for its school, stressing research on finance and technology-based management" (Antunes \& Thomas, 2007).

At the other end of the spectrum, prestigious business schools, mostly US, address a global audience, leveraging their global brand equity and the prestige derived from their research in top journals.

\section{Risk profile dictates international vs. global engagement}

With two schools of thoughts on the topography of the world (flat vs. not flat, globalized vs. semi-globalized), we observed that the Uppsala model refers mostly to internationalization. Indeed, it describes the path to internationalize as a step-by-step process while globalization is framed as a unique model to train global managers wherever they are. 
Since there is no definite and uncontested answer on the world's topography, business school leaders manage that ambiguity around internationalization and globalization. Facing tremendous competitive pressures, they must resolve tensions to accomplish anything at all. In most cases, the US flagship (large) MBA programs are mostly domestically focused, offering an international experience to foreign students. Europe internationalization has been institutionalized decades ago (Engwall, 2007) under the support of the European programs, such as Erasmus, beautifully described in the film "L'Auberge Espagnole" directed by Cédric Klapisch. Smaller executive MBA programs, closer to the corporate world by definition, are used to experiment globally and attract most resources within top business schools, whereas full-time programs are considered cash-cows, not growth products.

"If there was a big change, I would say in terms of the school's internationalization, it was really when the G [executive] program started [in the mid 1990's]. That was a really entrepreneurial venture; we didn't know whether it would work or not. It was all over the world, and it had students from all over the world. And the one thing I don't think anybody anticipated was that it would be putting US2 business school on the map internationally. It was incredible, because every place we went, the reporters came out to report, the business reporters came out."

Founding Faculty member, US2 business school

“.. With the G and the C [executive] programs, you could argue that the school leadership over the decades have certainly seen the value of globalization of business education."

Associate Dean, Executive Education, US2 business school

This experimental process is very useful to mitigate financial and reputational risks associated with IBCs or FDI in general. FDI, the ultimate way to go global, can also be perceived as an escape from the constraints of the institutional environment at home (Witt \& Lewin, 2007). At 
any rate, internationalization may well have been put in containers: import, export, FDI or in a cage even, whether it be that of Ghemawat or DiMaggio. However, internationalization should remain fluid and borderless, like ideas. Fulfilling their core mission, business schools supply the knowledge that is needed (global/universal vs. international/market-specific) while experts note that much work remains to be done.

"Globalization means that there's a global market for education but there's also global phenomena of people wanting to learn and they see education as a way forward and as a way of spreading knowledge."

Director, Doctoral School, FR3 business school (3/14/2014)

“./. Faculty members who come here get their PhD from the US, spend five years, then go back to India and so, you know, in terms of ability or knowledge base they are equivalent. They then put it in the local context and then help businesses."

Adjunct Associate Professor of the Practice, US2 business school (2/18/2014) “./.There's still so much more potential...for developing the global management capabilities, to produce the type of new knowledge that we need in business for a more international environment."

AACSB International Senior Executive (5/7/2014)

A closer look at the internationalization models and mechanisms reviewed in the literature highlights similarities (partnering and outsourcing), differences (import vs. export of ideas) and gaps. Among the gaps, we observe that the models are geographic in nature; they address geographic boundaries. However, internationalization is also about knowledge: its creation and its dissemination. Ideas are borderless. The annual reports of Harvard Business School have given us a hint as to where the field is going. Since 2011, internationalization has been one of 
their top priorities and their objective has been crystal clear: "internationalization to create global knowledge."7

We also note two additional models that are evolving: technology transfer and joint ventures. Since 2010, Fuqua has even engaged in a technology transfer of sorts, providing consulting services to Nazarbayev University in Kazakhstan to create a new business school in Astana (Tolo, Method, French, Rodhes, \& Allison, 2011). This goes beyond the import of ideas model since there is an active collaboration between institutions at the staff and faculty levels that often travel between the two locations. A similar transfer of technology happened between 1997 and 2001 to create the Indian School of business, linking Kellogg, Wharton, and LBS in that venture. This "strong association with renowned business schools ensures that the curriculum is up-todate in terms of theoretical intensity and practical relevance."8

Joint ventures saw the light of day in the US when UNC-Kenan Flagler, the first prominent business school to develop such a relationship, started to work with $2 \mathrm{U}$ (formerly 2tor) for technology support and some marketing ${ }^{9}$. Others followed suit: The Smith School of Business at the University of Maryland has been collaborating with Pearson (owners of the Financial Times) and Thunberbird with Laureate Corporation Inc., a commercial education company. However, in the case of the latter, the joint venture failed to receive support from the regional accreditation body $^{10}$ and Thunderbird had to find an alternative with the local university (Arizona State University) in order to survive. Does this create a new basis for thriving?

Strategic manoeuvers are very similar amongst business schools. However, the engine of internationalization/globalization differs. It is based on prestige (highly ranked) for globalization

\footnotetext{
${ }^{7}$ http://www.hbs.edu/annualreport/2012/features/internationalization.html

${ }_{9}^{8}$ http://www.isb.edu/post-graduate-programme-in-management

9 http://www.ft.com/cms/s/2/9fabac92-8fe3-11 le2-ae9e-00144feabdc0.html?ftcamp=published links\%2Frss\%2Fbusiness-education\%2Ffeed\%2F\%2Fproduct\#axzz2RaBzHc96

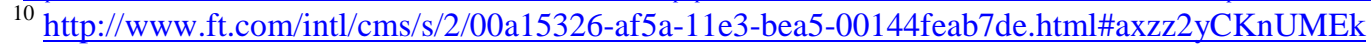


and reputation and accreditation for internationalization. The three tensions (internationalization or globalization, market enactment, and risk profile of engagement) challenge the taken-forgranted Uppsala model. They question the model which predicts a step-by-step internationalization through different and complementary actions: exportation, partnering, networking, outsourcing, and FDI.

As for well-known architecture firms (Caravan et al., 2012), business schools may be global, targeting global managers. Their expansion is based on their renown. They are not targeting numbers but rather elite membership. The main risk is the erosion of reputation which may reduce the attractiveness and the ability to charge a price premium. The globalization strategy supposes the ability to attract global managers of multinational companies and to train them on a regular basis to be able to create a network of global managers. It also supposes the ability to give them a global experience i.e. training within different countries, delivered by leading scholars. Global business schools limit their expansion and their network to maintain elitism and selectivity. The globalization strategy does not follow the Uppsala model as it is not based on the formation of a campus abroad, be it through partnership, FDI or network. Business schools simply need high quality facilities abroad to host training sessions, be it a proprietary campus or shared facilities. Attractiveness is based on the brand and renown. Such business schools are limited in numbers, maybe to one or two per country.

Most business schools are internationalizing; i.e., they are replicating their national model abroad. They are using the same mechanisms, FDI when investing in a campus abroad, partnering or networking. Internationalization is based on certification, accreditation, and quality standards. In each case, the mechanisms are similar but the engine is different. When 
globalization is targeted, renown and prestige are the main engine, whereas certification, accreditation, and quality standards are the engine of internationalization.

To be able to anticipate risk and to support international dynamism, it is important not only to identify the mechanisms by which business schools are internationalizing but also the engine of globalization or internationalization. Most of global players have no accreditation or quality standard. This is not an engine for them as renown and prestige are the main engines while they are playing a key role for internationalization of business school activities.

\section{PRACTICAL IMPLICATIONS}

Business school internationalization strategies have been based on imitation. Because internationalization seems to be a must, all business schools deploy most of the strategic manoeuvers to become international. The Uppsala model is the implicit model of reference for all business schools. It creates little differentiation amongst business schools but contributes to domestic legitimacy.

When the engine of internationalization/globalization is integrated, we can sum up four practical implications:

1. To make a difference through internationalization, it is necessary to understand what is the engine of internationalization for the business school.

It could be setting up the standard of management, as elite business schools are doing, implementing a global strategy through FDI, alliances, and intellectual domination. It could also be the creation of a network of specialized business schools worldwide to design an international training path. Three main questions have to be asked to define and implement a strategy: 1) what is the targeted audience (global managers or local managers who need to understand the internationalization processes and act internationally)? 2) What are the key social capital assets 
(reputation, prestige, accreditations, quality signals, etc.) and how far does the business school reputation reach? Finally, can the business school find reliable partner schools locally or is the creation of an international branch campus (IBC) required?

2. Imitation of the leaders in the field does not imply that audiences and market segments are similar.

Diversity of strategies, based on different audiences, should prevail over uniformity and convergence, as the business school field is maturing.

While many see a firm's physical presence as a proof of "globalness," business schools produce and disseminate knowledge that does not require a shell. A global strategy does not necessarily imply an IBC strategy. It can consist of the export of knowledge globally (e.g., strategy used by Harvard Business School and FR2 business school).

3. Prestige and reputation are critical assets of a very different value to business schools.

Either one is required to internationalize. However, prestige seems to be the most valuable asset and key success factor for the flawless implementation of a global strategy.

4. MOOCs (Massive Open online Course), the last manoeuver to produce global knowledge The past two years forced actors to face a new question: how to deal with the MOOCs that change the scale and pose a threat? Dean Richard Lyons, Haas business school at UC Berkeley, predicts that $50 \%$ of the US business schools could disappear within five to ten years due to online courses (Clark, 2014)! MOOCs might redefine the campus, the role and visibility of the faculty, learning itself, and the student experience in large online communities.

The MOOCs represent a real strategic challenge for business schools. Indeed, prestigious business schools aim to train the elite; i.e., a very small proportion of the managers who are supposed to be selected to rapidly become top managers. They have been leading the MOOC 
movement which is supposed to offer mass market high quality knowledge. On the one hand, it provides the masses with high quality knowledge and enhances the general managerial abilities of managers. On the other hand, it erects barriers of entry around the academic field. Top quality research becomes a necessary but insufficient condition to be influential in the field. Effective dissemination mechanisms like MOOCs are required in addition to journal articles, journal editorship, books and conferences.

In that process, elite schools could also force out some competitors whose course content has become a commodity, starving tuition-fees-dependent business schools (Guillotin \& Mangematin, 2014). Global knowledge has been the holy grail of management education and it seems that no price or sacrifice is too small to acquire it. Time and audiences will tell if MOOCs might become a mean to that end.

\section{CONCLUSIONS}

Business schools provide great insights to both practitioners and scholars studying internationalization. The combination of internationalization perception, audience selection, local isomorphic pressures, and risk profile leads to strategies that are international or global in scope. That combination will also define the international or global engagement and related activities of a business school.

Business-degree-granting institutions are spreading fast around the world to satisfy the global demand for education. In 2011, the AACSB estimated their number at 13,600 (Nelson, 2011) and at 16,371 as of August $2014^{11}$. As Engwall and Kipping (2013) reminded us, though, internationalization has its limitations and they are associated with the fact that, except for the few global jobs at a few global companies, labor markets are essentially domestic. If the role of

\footnotetext{
${ }^{11}$ http://www.aacsb.edu/about/our-reach/
} 
business schools is to create and disseminate knowledge to prepare for the business world, these limitations cannot be ignored if deans do not want to have dissatisfied and jobless graduates. If the world is not flat and labor markets are considered mostly domestic, should business schools that produce market-specific knowledge sheepishly pursue global strategies? Or should they admit that internationalization has its limitations and so do they? Crafting the right strategy will not only be smart, it will be vital. While our research findings cannot be generalized, they are applicable to PSFs and knowledge-intensive service firms in general.

\section{REFERENCES}

AACSB. 2011. Globalization of Management Education: Changing International Structures, Adaptive Strategies, and the Impact on Institutions.: Emerald Group Publishing.

Alajoutsijärvi, K., Juusola, K., \& Lamberg, J.-A. 2014. Institutional Logic of Business Bubbles: Lessons From the Dubai Business School Mania. Academy of Management Learning \& Education, 13(1): 5-25.

Antunes, D., \& Thomas, H. 2007. The Competitive (Dis)Advantages of European Business Schools. Long Range Planning, 40(3): 382-404.

Bartell, M. 2003. Internationalization of universities: A university culture-based framework. Higher Education, 45(1): 43-70.

Bazeley, P., \& Jackson, K. 2013. Qualitative data analysis with NVivo: Sage Publications Limited.

Birkinshaw, J., Brannen, M. Y., \& Tung, R. L. 2011. From a distance and generalizable to up close and grounded: Reclaiming a place for qualitative methods in international business research. Journal of International Business Studies, 42(5): 573-581.

Bowman, N. A., \& Bastedo, M. N. 2011. Anchoring effects in world university rankings: Exploring biases in reputation scores. Higher Education, 61(4): 431-444.

Brewer, D. J., Gates, S. M., \& Goldman, C. A. 2002. In pursuit of prestige: Strategy and competition in U.S. higher education: New Brunswick (U.S.A.) and London (U.K.): Transaction Publishers.

Bruner, R. F., \& Iannarelli, J. 2011. Globalization of Management Education. Journal of Teaching in International Business, 22(4): 232-242.

Burton, R. M., \& Obel, B. 2011. Computational modeling for what-is, what-might-be, and whatshould-be studies-And triangulation. Organization Science, 22(5): 1195-1202.

C-BERT. 2014. Branch campus listing as of 5/29/2014: SUNY, Albany, NY.

Caravan, D., Sharkey Scott, P., \& Mangematin, V. 2012. Aligning Strategies for Growth and Talent Management in Creative Professional Service Firms. Journal of Business Strategy, 34(3): 24-32.

Charmaz, K. 2006. Constructing grounded theory: A practical guide through qualitative research: London: Sage. 
Clark, P. 2014. Online Programs Could Erase Half of U.S. Business Schools by 2020, Bloomberg Businessweek.

Czinkota, M. R., Grossman, D. A., Javalgi, R. R. G., \& Nugent, N. 2009. Foreign market entry mode of service firms: The case of US MBA programs. Journal of World Business, 44(3): 274-286.

De Meyer, A., Harker, P., \& Hawawini, G. 2004. The globalization of business education, in H. Gatignon and J. Kimberly (eds.) The INSEAD-Wharton Alliance on Globalizing: Strategies for Building Successful Global Businesses, Cambridge: Cambridge University Press.

Denzin, N. K., \& Lincoln, Y. 2000. Qualitative research. Thousand Oaks ua.

Doh, J. P. 2010. From the Editors: Why Aren't Business Schools More Global and What Can Management Educators Do About It? Academy of Management Learning \& Education, 9(2): 165-168.

Doz, Y. 2011. Qualitative research for international business. Journal of International Business Studies, 42(5): 582-590.

Durand, R., \& McGuire, J. 2005. Legitimating Agencies in the Face of Selection: The Case of AACSB. Organization Studies, 26(2): 165-196.

Eisenhardt, K. M. 1989. Building Theories from Case Study Research. The Academy of Management Review, 14(4): 532-550.

Eisenhardt, K. M., \& Graebner, M. E. 2007. Theory Building from Cases: Opportunities and Challenges. The Academy of Management Journal, 50(1): 25-32.

Engwall, L. 2007. The anatomy of management education. Scandinavian Journal of Management, 23(1): 4-35.

Engwall, L. 2013. Academic Taxi Drivers in Global Markets. Mercury, 1(3): 25-27.

Engwall, L., \& Kipping, M. 2013. The Internationalization of International Management Education and Its Limitations.

Espeland, W. N., \& Sauder, M. 2007. Rankings and Reactivity: How Public Measures Recreate Social Worlds1. American Journal of Sociology, 113(1): 1-40.

Flick, U. 2007. Designing qualitative research. Los Angeles ; London: SAGE.

Forsgren, M. 2002. The concept of learning in the Uppsala internationalization process model: a critical review. International Business Review, 11(3): 257-277.

Friedman, T. L. 2005. The world is flat : a brief history of the twenty-first century. New York: Farrar, Straus and Giroux.

Ghemawat, P. 2007a. Redefining global strategy. Boston: Harvard Business School Publishing.

Ghemawat, P. 2007b. Why the world isn't flat. Foreign policy: 54-60.

Ghemawat, P. 2008. The globalization of business education: through the lens of semiglobalization. The Journal of Management Development, 27(4): 391-414.

Ghemawat, P. 2011. World 3.0 : global prosperity and how to achieve it. Boston, Mass.: Harvard Business Review Press.

Gordon, R. A., \& Howell, J. E. 1959. Higher education for business. New York: Columbia University Press.

Guillotin, B., \& Mangematin, V. 2014. Moocs may create a global trail of failed business schools, FT.com, Financial Times, London, UK

Hudzik, J. K. 2011. Comprehensive internationalization: From concept to action. 
Javalgi, R. R. G., \& Grossman, D. A. 2014. Firm Resources and Host-Country Factors Impacting Internationalization of Knowledge-Intensive Service Firms. Thunderbird International Business Review, 56(3): 285-300.

Johanson, J., \& Vahlne, J.-E. 1977. The internationalization process of the firm-a model of knowledge development and increasing foreign market commitments. Journal of international business studies: 23-32.

Johanson, J., \& Vahlne, J.-E. 2009a. The Uppsala internationalization process model revisited: From liability of Foreignness to Liability of Outsidership. Journal of International Business Studies, 40(9): 1411-1431.

Johanson, J., \& Vahlne, J. 2009b. The Uppsala internationalisation process model revisited: from liability of foreignness to liability of outsidership. Journal of International Business Studies, 40: 1141-1431.

Khurana, R. 2007. From Higher Aims to Hired Hands : The Social Transformation of American Business Schools and the Unfulfilled Promise of Management As a Profession. Princeton: Princeton University Press.

Knight, J. 1999. Quality and internationalisation in higher education. Paris: Organisation for Economic Co-operation and Development.

Knight, J. 2004. Internationalization Remodeled: Definition, Approaches, and Rationales. Journal of Studies in International Education, 8(1): 5-31.

Korn, M. 2014. Corporate News: Thunderbird Ends Laureate Venture, Wall Street Journal, 2014 Apr 10, Eastern edition ed. New York, N.Y.

Levitt, T. 1983. The globalization of markets. Harvard Business Review, 61(3): 92-102.

Luijten-Lub, A., Van der Wende, M., \& Huisman, J. 2005. On cooperation and competition: A comparative analysis of national policies for internationalisation of higher education in seven Western European countries. Journal of Studies in International Education, 9(2): 147-163.

Miles, M. B., \& Huberman, A. M. 1994. Qualitative data analysis: An expanded sourcebook: Sage.

Naidoo, V. 2006. International education: A tertiary-level industry update. Journal of Research in International Education, 5(3): 323-345.

Nelson, C. 2011. The Global Spread of Business School Accreditation. AACSB International, The Association to Advance Collegiate Schools of Business.

Noy, C. 2008. Sampling knowledge: The hermeneutics of snowball sampling in qualitative research. International Journal of social research methodology, 11(4): 327-344.

Peräkylä, A. 1997. Reliability and validity in research based on tapes and transcripts. Qualitative research: Theory, method and practice: $201-220$.

Rugman, A. 2012. The end of globalization: Random House.

Rugman, A. M., \& Verbeke, A. 2004. A perspective on regional and global strategies of multinational enterprises. Journal of International Business Studies, 35(1): 3-18.

Rugman, A. M., \& Verbeke, A. 2007. Liabilities of regional foreignness and the use of firm-level versus country-level data: A response to Dunning et al.(2007). Journal of International Business Studies, 38(1): 200-205.

Saldaña, J. 2013. The coding manual for qualitative researchers (2nd ed.): Sage.

Scherer, R. F., Javalgi, R. R. G., Bryant, M., \& Tukel, O. 2005. Challenges of AACSB International accreditation for business schools in the United States and Europe. Thunderbird International Business Review, 47(6): 651-669. 
Stookey, S. 2008. The Future of Critical Management Studies: Populism and Elitism. Organization, 15(6): 922-924.

Thomas, L., Billsberry, J., Ambrosini, V., \& Barton, H. 2013. Convergence and Divergence Dynamics in British and French Business Schools: How Will the Pressure for Accreditation Influence these Dynamics? British Journal of Management.

Tolo, K., Method, F., French, J., Rodhes, J., \& Allison, C. 2011. BEST PRACTICES FOR U.S.A.I.D. INTERNATIONAL HIGHER EDUCATION INSTITUTIONAL PARTNERSHIPS: ASIA AND MIDDLE EAST REGIONS VOLUME I: 1-96.

Wedlin, L. 2006. Ranking business schools: Forming fields, identities and boundaries in international management education: Edward Elgar Publishing.

Wedlin, L. 2007. The role of rankings in codifying a business school template: Classifications, diffusion and mediated isomorphism in organizational fields. European Management Review, 4(1): 24-39.

Wedlin, L. 2011. Going global: Rankings as rhetorical devices to construct an international field of management education. Management Learning, 42(2): 199-218.

Wilkins, S., \& Huisman, J. 2011. Student Recruitment at International Branch Campuses: Can They Compete in the Global Market? Journal of Studies in International Education, 15(3): 299-316.

Wilkins, S., \& Huisman, J. 2012. The international branch campus as transnational strategy in higher education. Higher Education, 64(5): 627-645.

Wilson, M., \& Sapsford, R. 2006. Data collection and analysis. London, Sage Publications Ltd.

Witt, M. A., \& Lewin, A. Y. 2007. Outward foreign direct investment as escape response to home country institutional constraints. J Int Bus Stud, 38(4): 579-594.

Yin, R. K. 2009. Case study research : design and methods. Los Angeles, Calif.: Sage Publications. 